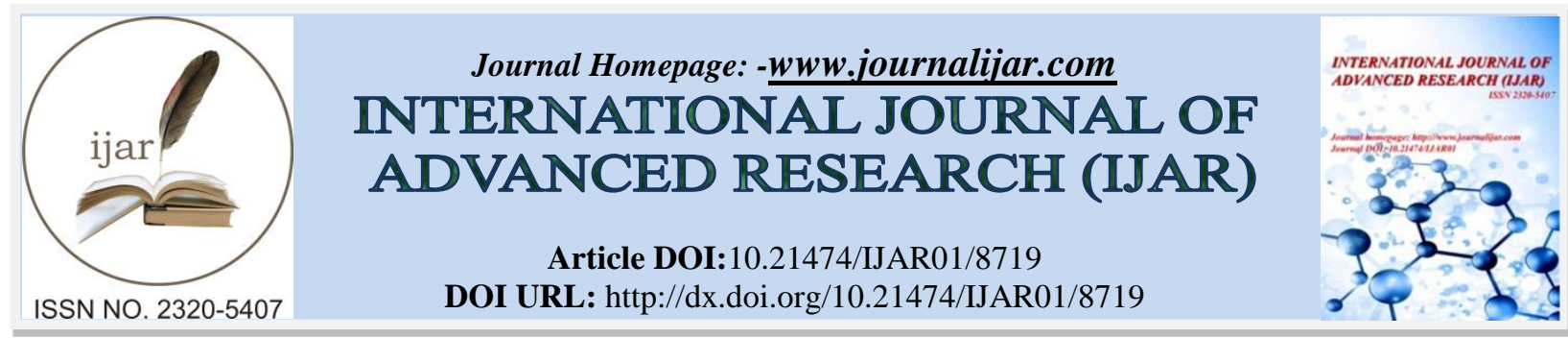

RESEARCH ARTICLE

\title{
CROWDFUNDING IN INDIA: AN EMPIRICAL STUDY.
}

Dr. G V M Sharma, Dr. Anitha. S. Yadav and Prakruthi. N Udupa.

Associate Professor, RNSIT Banglore, Professor, Presidency University, Bangalore, Assistant Professor, PES University Bangalore.

\section{Manuscript Info}

\section{Manuscript History}

Received: 17 January 2019

Final Accepted: 19 February 2019

Published: March 2019

Key words:-

Crowdfunding, crowd investments, Start-ups funding, Financing.

\section{Abstract}

Crowdfunding is a method of acquiring project funding, by soliciting contributions from a large group of people typically via internet or through social networking websites like Facebook, Tumblr, LinkedIn, Twitter or crowdfunding websites (Ketto, Kikstarter, GoFundMe, Crowdrise etc). The website platform acts as a mediator between the Project Campaigner or Entrepreneur and crowd or investors in sourcing funds from the crowd at large. According to Statista Market forecast "the Transaction Value in the Crowdfunding section totals up to US\$6m in 2017. This Transaction Value is forecasted to show Compounded annual growth rate of $30.6 \%$ by $2017-2022$, which totals up to US $\$ 22 \mathrm{~m}$ in 2022 .On an average funding raised per venture in 'Crowdfunding' segment sums up to US\$171.50 in 2017.When compared globally, it is seen that highest transaction value reached is US\$ $4,920 \mathrm{~m}$ in China in the year of 2017. In India crowdfunding is in nascent stage and evolving. It started in 2009 after 2008 financial crisis. It is gaining momentum and more people are taking interest in supporting start-ups, film industry, and community development activities by way of crowdfunding. The present study is an attempt to determine the awareness level and identify the factors leading to investments in crowdfunding. The study identified six factors which play a prominent role in the growth of crowdfunding.

Copy Right, IJAR, 2019,. All rights reserved.

\section{Introduction}

Crowdfunding is a method for acquiring funds by soliciting contributions from a large group of people typically via internet or through social networking websites like Facebook, Tumblr, LinkedIn, Twitter and even committed crowdfunding websites like Ketto, Kikstarter, GoFundMe, Crowdrise etc. The website platformer acts as a mediator between the Project Campaigner and crowd or investor. Crowd funding concept originated in the US and UK.It is emerging as an substitute for raising capital in India. According to Statista Market forecast, the Transaction Value in the "Crowdfunding" section totals up to US\$6m in 2017. This Transaction Value is forecasted to show compounded annual growth rate of $30.6 \%$ by $2017-2022$, which totals up to US $\$ 22 \mathrm{~m}$ in 2022 .On an average funding raised per venture in 'Crowdfunding' segment sums up to US\$171.50 in 2017. When compared globally, it is seen that highest transaction value reached is US\$ 4,920m in China in the year of 2017. Acquisition of funds is a task in itself for any business undertaking. Crowdfunding has emerged as another approach to raise capital for new business undertakings, philanthropies and even new entrants.. Another type of capital arrangement that rose in the 
wake of monetary emergency of 2008 has helped private ventures and new businesses with an opportunity to build their online networking nearness, speculation base and financing prospects.

Crowdfunding sites serve as an online exchange entry that interfaces speculators and independent enterpreneuers in new ventures. Worldwide crowdfunding has seen huge development for the last couple of years. Crowdfunding is anticipated as one of the key elements for changing the flow of the world's economy by the specialists. Massolution estimates $26.87 \%$ CAGR (compound annual growth rate) by 2020. As per Massolution estimates report, in 2015 the recokoned fundraising volume of the industry was $\$ 34$ billion.According tonTechnavio's market research analysis it has been estimated that by 2020 , the global crowdfunding market will grow at a CAGR of $27 \%$

\section{Literature Review}

At Present, there are very few published research work on Crowdfunding. In India, the concept of crowdfunding started in the year 2009 basically for start ups and film industry.

Several researchers have conducted studies on the models of crowd funding especially equity model, investment model and donation model of functioning of crowd funding, however, no major research has been done on practical problems and challenges faced by crowd funding platforms. Mitra,(2012) in his study explores the global market for crowdfunding, the principle of businesses to crowdfunding and the context of different crowdfunding models. The study found that crowdfunding as an alternative way financing is fast developing globally. Donation and reward-based sections are the largest group among three models of financing. On the other hand equity based funds are also raising funds in Europe and Australia. According to Macht\& Weatherston, (2014), Crowdfunding via Internet, a new fundraising tool for small business projects. This is advantageous for fund-seeking companies, as it enables them to overcome fundraising difficulties, provides entrepreneurs value-added involvement like publicity and contacts and increasing access to further fundraising, and also have an advantage of limited or no loss of control and ownership . Meyskens \& Bird, (2015) in their study examined the role of crowdfunding in social projects funding and provided insights into crowdfunding types ,platforms and social value creation. According to Golic,(2014) crowdfunding is an alternative means of financing Small and Medium Enterprises(SME) . Mollick, \& etal., (2016) explain that crowdfunding open the doors of opportunities for new projects and innovative ventures, as well as a new investment option for investors. They opine that this also eliminates middlemen and involves crowd in funding and backing projects. According to Mitra, D (2012), crowdfunding is characterized as the financing of a venture by individuals (the crowd) instead of 'certified' professional entities or individuals like banks, Venture Capitalists or businesses. In a study by Siering(2016), sample of fraudulent and nonfraudulent ventures published at crowdfunding platforms was analysed,and the study proposed fraud detection mechanism for increased trust towards user platforms. The proposed technique could be applied to identify fraudulent behaviour and to add value for the platform's participants

\section{Models of Crowdfunding an Overview}

According to a SEBI release in 2014, a Consultation paper on 'Crowdfunding in India', defined crowdfunding as "solicitation of funds (small amount) from multiple investors through a web-based platform or social networking site for a specific project, business venture or for a social cause."As there are many alternatives of capital raising in businesses at different growth stages, similarly there are different types of crowdfunding. Crowdfunding method depends on the type of product or service you offer. There are basically three kinds namely - Donation based, Reward based and Equity crowdfunding. A brief of these models is provided below.

\section{Donation-Based Crowdfunding}

The donation model of crowdfunding is for the philanthropy reasons; here funds are raised for social or philanthropic activities. The model uses online stage where the group empowers individuals to contribute to a venture. There are numerous sites which enable the model to easily raise funds for individual or for some charitable reasons like funding major medical bills . calamity help, or development of society initiatives like construction of roads, bridges etc. In this model the contributor is self-motivated and has greater amount of social inspiration. The contributor will be getting reward as intangible benefits which are not quantifiable.

\section{Rewards-Based Crowdfunding}

One of the most recognized type of crowdfunding is reward based crowdfunding. Under this model, an investor provides funds in exchange for a reward in the form of product or service offered by the company. This model primarily finances social and entrepreneurial undertakings. It based on the principle of non money related prizes the 
model works on the basis of recognition -related rewards or similar to a presale agreement. It kick-starts the exercise and permits the recipient to act as donors. Thus reward based crowdfunding involves investors providing funds to the business in exchange of reward. Despite the fact that this technique offers supporters a reward, it's still by and large considered a subset of donation based crowdfunding. This method is the most popular option here on Fundable as well on other popular crowdfunding platforms like Kickstarter and Indiegogo, because it allows business owners to reward the investors without incurring extra expense or dilution of ownership. According to E. Kirby and S Worner, Equity-based crowdfunding is a act of solicitation of funds by businesses from investors via online platform in exchange of issuance of securities such as equity shares or ownership in the company.

\section{Lending Model}

Under Peer -to-Peer (P2P) lending, an online platform acts as an intermediary between investors and borrowers where investors provide unsecured loans to issuers and interest rates are set by the platform. In P2P platforms organizes loan between individuals, where as other platforms raise funds which are in turn lend to small and medium sized businesses. P2P lending is like unsecured loan where investors are not protected by the way of any compensation scheme to cover defaults in this market. These investments are highly risky and investors may lose significant proportion of their investments in case of any default.

\section{Objectives of the study}

1. To determine the awareness level of Crowd Funding System.

2. To explore the factors that lead to investing in crowd funding

\section{Research Methodology:-}

Survey method has been followed for research and the data has been collected with a structured questionnaire. The questionnaire contained demographic characteristics of the respondents, questions on awareness level, preferences of investments avenues and factors determining investment in crowdfunding. The respondents were asked to rate 21 variables on a Five point Likert scale ranging from 1 Strongly Disagree to 5 Strongly agree. The data was collected from 384 respondents residing in Bangalore City. Convenience sampling method was adopted for selecting the respondents. A total of 400 questionnaires were distributed, out of which 384 filled questionnaires were received and only 378 were filled up in all respects were considered for analysis.

\section{Need for the study}

India is the fastest growing eco-system for start-ups. After the US and UK, India is the 3rd largest in terms of startups in technology sector. On the other hand, India is facing withdrawal of start-ups expecting more supporting regulatory policies or regimes. For example - Singapore offers many benefits for start-ups which include flexible compliance requirements, zero capital gains, tax credits to motivate investors for investment and grants support for R\&D. Whereas, in India start-ups suffers from high taxation regimes, excessive bureaucracy at incorporation , fundraising stages and weak patent laws. Admitting the potential of start-ups in fostering the economy, SEBI(Securities Exchange Board of India) has made reforms to improve the access of funds for SMEs (Small And Medium Enterprises) and start-ups. In 2012 SEBI amended the Alternative Investment Funds Regulations, to regulate 'Angle Funds'. The flexibility in SME listing regime was made under Chapter XB of the SEBI (Issue of Capital and Disclosure Requirements) regulations in 2009 which allowed separate SME trading platform at the stock exchange. A 'consultation paper on crowd funding in India was released in 2014 by SEBI to invite suggestions from stakeholders on regulatory proposals. Though there are various financing avenues in the Indian Financial system but they have complex procedures and many legal restrictions. Most of the times it is difficult for the investors to judge risk-return level as the investment involves regulatory issues. As a new investment source, crowd funding has just started in India, there is a need to study and analyse crowd funding in terms of return, risk involved, awareness level, factors leading to investments in Crowdfunding, as an alternate channel of investment, donations and peer-to-peer lending. The present study is an attempt to determine the awareness level and identify the factors contributing to investments in crowd funding.

\section{Limitations:}

1. Respondents may not have the complete knowledge of crowd funding

2. Rural respondents are not considered as the questionnaire is administered in Bangalore city.

3. Lack of computer literacy is a limitation as crowd funding is internet based system.

4. The responses provided by the respondents may be biased. 
Data Analysis and Interpretation

Table No 1:-showing Demographic characteristics of the respondents

\begin{tabular}{|c|c|c|c|c|}
\hline \multicolumn{5}{|c|}{ Demographic Profile of the Respondents } \\
\hline Sl.No. & & & Frequency & Per cent \\
\hline \multirow[t]{3}{*}{1} & \multirow[t]{3}{*}{ Gender } & Male & 200 & 52.9 \\
\hline & & Female & 178 & 47.1 \\
\hline & & Total & 378 & 100 \\
\hline \multirow[t]{6}{*}{2} & \multirow[t]{6}{*}{ Age } & Less Than 30 & 34 & 9 \\
\hline & & $31-40$ & 56 & 14.8 \\
\hline & & $41-50$ & 84 & 22.2 \\
\hline & & $51-60$ & 125 & 33.1 \\
\hline & & Above 60 & 79 & 20.9 \\
\hline & & Total & 378 & 100 \\
\hline \multirow[t]{5}{*}{3} & \multirow[t]{5}{*}{ Qualification } & SSLC & 12 & 3.2 \\
\hline & & PUC & 137 & 28.8 \\
\hline & & Graduate & 109 & 36.2 \\
\hline & & Post Graduate & 120 & 31.8 \\
\hline & & Total & 378 & 100 \\
\hline \multirow[t]{6}{*}{4} & \multirow[t]{6}{*}{ Occupation } & Salaried & 136 & 36 \\
\hline & & Self employed & 104 & 27.5 \\
\hline & & Professional & 78 & 20.6 \\
\hline & & Business & 55 & 14.6 \\
\hline & & Others & 5 & 1.3 \\
\hline & & Total & 378 & 100 \\
\hline \multirow[t]{6}{*}{5} & \multirow[t]{6}{*}{ Income } & Below 3,00,000 & 81 & 19.3 \\
\hline & & $3,00,000-500000$ & 73 & 21.4 \\
\hline & & $500000-1000000$ & 96 & 25.5 \\
\hline & & $1000000-1500000$ & 87 & 23 \\
\hline & & Above 1500000 & 41 & 10.8 \\
\hline & & Total & 378 & 100 \\
\hline
\end{tabular}

Source:PrimaryData

Table No. 1 shows the demographic profile of the respondents. The table indicates that majority ie., 52.9 percent of the respondents are male and 47.1 percent of the respondents are female. In the age group majority of the respondents (33.1 percent) are the age group of 51 to 60 years, followed by 41 to 50 years (22.2 percent), above 60 years of age (20.9 percent), between 31 to 40 years (14.8 percent) and 9 percent are in the age group of less than 30 years. Further in educational qualification majority ( 36.2 percent) of the respondents are graduates , followed by post graduate of (31.7 Percent) of the respondents and the remaining respondents are PUC and SSLC qualified 28.8 percent and 3.2 percent respectively .Regarding occupation of the respondents majority 36 percent of the respondents are salaried followed by self employed (27.5 percent) , professional (20.6 percent ), Business (14.6 percent ) and others( pensioners housewife) are only 1.3 percent of the total respondents.

In the income group majority ( 25.5 percent) of the respondents are the income group of 5 lakhs to 10 lakhs, 23 percent of the respondents come from the income group of 10 lakhs to 15 lakhs, followed by 3 lakhs to 5 lakhs ie,21.4 percent, below 3 lakhs- 19.3 percent and above 15 lakhs income the least 10.8 percent.

Table No 2:-Showing the Awareness level of Respondents

\begin{tabular}{|l|l|l|l|l|l|}
\hline & & Frequency & Percent & Valid Percent & Cumulative Percent \\
\hline Valid & Yes & 129 & 34.1 & 34.1 & 34.1 \\
\cline { 2 - 6 } & No & 249 & 65.9 & 65.9 & 100.0 \\
\cline { 2 - 6 } & Total & 378 & 100.0 & 100.0 & \\
\hline
\end{tabular}


Table No. 2 shows the awareness level of the respondents in crowd funding. The table clearly indicates that majority of the respondents 65.9 percent are unaware of crowd funding and only 34.1 percent are aware of crowd funding as a financial investment option.

Table No 3:- Showing Preference in Various Investment Options

\begin{tabular}{|c|c|c|c|}
\hline Policy & & Frequency & Percent \\
\hline \multirow[t]{3}{*}{ Post office scheme } & Yes & 179 & 47.4 \\
\hline & No & 199 & 52.6 \\
\hline & Total & 378 & 100 \\
\hline \multirow[t]{3}{*}{ Savings deposit } & Yes & 200 & 52.9 \\
\hline & No & 178 & 47.1 \\
\hline & Total & 378 & 100 \\
\hline \multirow[t]{3}{*}{ Fixed Deposit } & Yes & 278 & 73.5 \\
\hline & No & 100 & 26.5 \\
\hline & Total & 378 & 100 \\
\hline \multirow[t]{3}{*}{ Recurring Deposit } & Yes & 154 & 40.7 \\
\hline & No & 224 & 59.3 \\
\hline & Total & 378 & 100 \\
\hline \multirow[t]{3}{*}{ Stock Market } & Yes & 66 & 17.5 \\
\hline & No & 312 & 82.5 \\
\hline & Total & 378 & 100 \\
\hline \multirow[t]{3}{*}{ Derivatives } & Yes & 41 & 10.8 \\
\hline & No & 337 & 89.2 \\
\hline & Total & 378 & 100 \\
\hline \multirow[t]{3}{*}{ Mutual Funds } & Yes & 82 & 21.7 \\
\hline & No & 296 & 78.3 \\
\hline & Total & 378 & 100 \\
\hline \multirow[t]{3}{*}{ Gold Bonds } & Yes & 98 & 25.9 \\
\hline & No & 280 & 74.1 \\
\hline & Total & 378 & 100 \\
\hline \multirow[t]{3}{*}{ Govt Bonds } & Yes & 94 & 24.9 \\
\hline & No & 284 & 75.1 \\
\hline & Total & 378 & 100 \\
\hline \multirow[t]{3}{*}{ Crowdfunding } & Yes & 98 & 25.9 \\
\hline & No & 280 & 74.1 \\
\hline & Total & 378 & 100 \\
\hline \multirow[t]{3}{*}{ PPF } & Yes & 127 & 33.6 \\
\hline & No & 251 & 66.4 \\
\hline & Total & 378 & 100 \\
\hline \multirow[t]{3}{*}{ Real estate } & Yes & 92 & 24.3 \\
\hline & $\mathrm{No}$ & 286 & 75.7 \\
\hline & Total & 378 & 100 \\
\hline
\end{tabular}

Source: Primary Data

Table No.3 Shows the preference of the respondents in various investment avenues. The table clearly indicates that majority i.e., 73.5 percent of the respondents prefer fixed deposits, the second most preferred option is savings deposit amounting to 52 percent followed by post office scheme at 47.5 percent and recurring deposit at 40.7 percent. It is also observed that Mutual funds, Government Bonds, Real estate, Crowd funding and public provident fund have on an average a preference of $25 \%$

\section{Factor Analysis}

The data collected through questionnaire were entered and analysed by using SPSS. There are 21 variables determining the basis of investments in crowd funding quoted in the questionnaire. Data reduction is done through 
factor analysis by principal component method and the following results are obtained. To check whether the data is suitable for factor analysis, the following steps are taken: i) the correlation matrices are computed and it is found that $\mathrm{r}$ is greater than .30, anything lower than .30 would indicate weak relationship between the variables (Tabachnick \& Fidell,2007). From table No 4 it is found that KMO measure of sampling adequacy is .803, Bartlett's Test of Sphericity with approximate Chi square value is 3.4323, p =.000 are statistically significant at 5 per cent level. Therefore, it can be concluded that variable considered for factor analysis form normal distribution.

Table No 4:-KMO and Bartlett's Test

\begin{tabular}{|l|l|r|}
\hline \multicolumn{2}{|c|}{ KMO and Bartlett's Test } & \\
\hline Kaiser-Meyer-Olkin Measure of Sampling Adequacy. & .803 \\
\hline Bartlett's Test of Sphericity & Approx. Chi-Square & 3.4323 \\
\cline { 2 - 3 } & df & 210 \\
\cline { 2 - 3 } & Sig. & .000 \\
\hline
\end{tabular}

\begin{tabular}{|c|c|c|}
\hline \multicolumn{3}{|l|}{ Communalities } \\
\hline & Initial & Extraction \\
\hline Safety & 1.000 & .544 \\
\hline Feasible & 1.000 & .710 \\
\hline Goal & 1.000 & .596 \\
\hline Returns & 1.000 & .663 \\
\hline Helping & 1.000 & .495 \\
\hline Incentive & 1.000 & .658 \\
\hline Reward & 1.000 & .649 \\
\hline Amount of funds & 1.000 & .828 \\
\hline Deadline & 1.000 & .637 \\
\hline Easy process & 1.000 & .724 \\
\hline Volume & 1.000 & .672 \\
\hline Unsecured investment & 1.000 & .596 \\
\hline Stock market risk & 1.000 & .785 \\
\hline Popular & 1.000 & .730 \\
\hline Monitoring & 1.000 & .824 \\
\hline Exemptions & 1.000 & .698 \\
\hline Transparency & 1.000 & .737 \\
\hline Recognition & 1.000 & .643 \\
\hline Monitoring agency & 1.000 & .755 \\
\hline Trustworthy & 1.000 & .554 \\
\hline Simplicity & 1.000 & .693 \\
\hline
\end{tabular}

\begin{tabular}{|c|c|c|c|c|c|c|c|c|c|}
\hline \multicolumn{10}{|c|}{ Total Variance Explained } \\
\hline \multirow[t]{2}{*}{$\begin{array}{l}\text { Componen } \\
\mathrm{t}\end{array}$} & \multicolumn{3}{|c|}{ Initial Eigenvalues } & \multicolumn{3}{|c|}{$\begin{array}{l}\text { Extraction Sums of Squared } \\
\text { Loadings }\end{array}$} & \multicolumn{3}{|c|}{$\begin{array}{l}\text { Rotation Sums of Squared } \\
\text { Loadings }\end{array}$} \\
\hline & Total & $\begin{array}{l}\% \text { of } \\
\text { Variance }\end{array}$ & $\begin{array}{l}\text { Cumulative } \\
\%\end{array}$ & Total & $\begin{array}{l}\% \text { of } \\
\text { Variance }\end{array}$ & $\begin{array}{l}\text { Cumulativ } \\
\text { e } \%\end{array}$ & Total & $\begin{array}{l}\% \text { of } \\
\text { Variance }\end{array}$ & $\begin{array}{l}\text { Cumulativ } \\
\text { e } \%\end{array}$ \\
\hline 1 & 5.568 & 26.512 & 26.512 & 5.568 & 26.512 & 26.512 & 3.066 & 14.602 & 14.602 \\
\hline 2 & 2.869 & 13.662 & 40.174 & 2.869 & 13.662 & 40.174 & 2.711 & 12.912 & 27.513 \\
\hline 3 & 1.921 & 9.148 & 49.322 & 1.921 & 9.148 & 49.322 & 2.694 & 12.827 & 40.340 \\
\hline 4 & 1.399 & 6.661 & 55.984 & 1.399 & 6.661 & 55.984 & 2.645 & 12.593 & 52.934 \\
\hline 5 & 1.239 & 5.900 & 61.884 & 1.239 & 5.900 & 61.884 & 1.816 & 8.647 & 61.581 \\
\hline 6 & 1.193 & 5.683 & 67.567 & 1.193 & 5.683 & 67.567 & 1.257 & 5.986 & 67.567 \\
\hline 7 & .830 & 3.951 & 71.518 & & & & & & \\
\hline 8 & .810 & 3.857 & 75.374 & & & & & & \\
\hline 9 & .755 & 3.597 & 78.972 & & & & & & \\
\hline 10 & .620 & 2.953 & 81.925 & & & & & & \\
\hline
\end{tabular}




\begin{tabular}{|l|l|l|l|l|l|l|l|l|l|}
\hline 11 & .508 & 2.420 & 84.345 & & & & & & \\
\hline 12 & .496 & 2.364 & 86.709 & & & & & & \\
\hline 13 & .483 & 2.300 & 89.009 & & & & & & \\
\hline 14 & .402 & 1.912 & 90.921 & & & & & & \\
\hline 15 & .384 & 1.829 & 92.750 & & & & & & \\
\hline 16 & .320 & 1.525 & 94.276 & & & & & & \\
\hline 17 & .283 & 1.346 & 95.622 & & & & & & \\
\hline 18 & .263 & 1.254 & 96.877 & & & & & & \\
\hline 19 & .254 & 1.211 & 98.087 & & & & & & \\
\hline 20 & .208 & .992 & 99.079 & & & & & & \\
\hline 21 & .193 & .921 & 100.000 & & & & & & \\
\hline
\end{tabular}

The above table shows that 21 variables are reduced to six variables showing a total variance of 67.567 percentage $14.602 \%, 12.912 \%, 12.827 \%, 12.593 \%, 8.647 \%$ and $5.987 \%$. Factor I The factor I consists of 6 variables showing the factors leading to investment in crowd funding which accounts for $14 \%$ of variance ie., Helping a startup ,incentives expected, investing considered as a reward when funding a project, amount of funds the project has already received motivates the funders in investment decisions.

Factor II consists of 4 variables possessing variance of $12.912 \%$ which indicates Transparency of financial data and volume of crowd funders, periodically monitored, and risk is akin to stock market. This factor is labelled as transparency which in turn increases the confidence of the investors.

Factor III comprises of 4 variables accounting for $12.827 \%$ of the variance and it signifies easy adaptability, investors looking for feasibility of project, the percentage of funding target achieved, and return on investment is considered important. This factor is named as financial feasibility in investing decisions.

Factor IV accounts for $12.593 \%$ consisting of 3 variables which includes usage of internet, mass reach through internet and trustworthyness as financial information is periodically monitored and these factors are labelled as mass reach factor.

Factor $\mathbf{V}$ has 2 variables which accounts for $8.647 \%$ and includes easy and simple procedure in crowd funding. Hence this factor is called as convenience factor.

Factor VI comprises 2 variables which accounts for 5.986\% of the variance. This includes funding target and deadline of the project this is labelled as goal oriented factor.

\section{Major Findings}

From the above study it is found that majority of the respondents (66\%) are unaware of crowdfunding as a financial investment option. As the study shows that majority of the respondents prefer fixed deposits or savings deposit (52\%) followed by post office scheme which indicates low risk appetite of investors as the above instruments provide risk free returns. The study found that there are six major factors which the investors consider while investing namely motivation as a reward, transparency, feasibility ,mass reach, accessibility and target oriented.

\section{Conclusion:}

From the above study it can be concluded that awareness level about crowdfunding in India is very low. The main reason being lack of support and incentives from government as crowdfunding platform is considered as unauthorized.Since the awareness level about various financial options is very low and risk-taking appetite of investors is less resulting in investing majorly in risk free instruments. There are 6 factors which leads to investment in crowd funding- Feasibility, Mass reach, Transparency, Rewards, Convenience and Goal orientation.Further Study can be conducted on respondents of different age groups to precisely understand the behaviour of investors towards crowdfunding. 


\section{References:-}

1. Freedman, Nutting (2015) A brief history of Crowdfunding including rewards, donation, debt and equity platforms

2. Golić, Z. (2014). Advantages Of Crowdfunding As An Alternative Source Of Financing Of Small And Medium-Sized Enterprises. Zbornik Radova Ekonomskog Fakulteta U Istocnom Sarajevu, (8), 39-48. doi:10.7251/ZREFIS1408039G

3. Lehner, O. M. (2013). Crowdfunding social ventures: a model and research agenda. Venture Capital, 15(4), 289-311. doi:10.1080/13691066.2013.782624

4. Mitra, D. (2012). The Role Of Crowdfunding In Entrepreneurial Finance. Delhi Business Review, 13(2), 67-72.

5. Macht, S. A., \& Weatherston, J. (2014). The Benefits of Online Crowdfunding for Fund-Seeking Business Ventures. Strategic Change, 23(1/2), 1-14. doi:10.1002/jsc.1955

6. Meyskens, M., \& Bird, L. (2015). Crowdfunding and Value Creation. Entrepreneurship Research Journal, 5(2), 155-166. doi:10.1515/erj-2015-0007

7. Mitra, D. (2012). The Role Of Crowdfunding In Entrepreneurial Finance. Delhi Business Review, 13(2), 67-72.

8. Mollick, E., \& Robb, A. (2016). Democratizing Innovation and Capital Access: The Role Of Crowdfunding. California Management Review, 58(2), 72-87. doi:10.1525/cmr.2016.58.2.72

9. Prinsha K (2016) A study on Crowdfunding and its implications in India". Indian Journal of Research. Volume 5 , issue 1 ,

10. Siering, M., Koch, J. A., \& Deokar, A. V. (2016). Detecting Fraudulent Behaviour on Crowdfunding Platforms: The Role of Linguistic and Content-Based Cues in Static and Dynamic Contexts. Journal of Management Information Systems, 33(2), 421-455.

11. Younkin, P., \& Kashkooli, K. (2016). What Problems Does Crowdfunding Solve?. California Management Review, 58(2), 20-43. doi:10.1525/cmr.2016.58.2.20

12. Younkin, P., \& Kashkooli, K. (2016). What Problems Does Crowdfunding Solve?. California Management Review, 58(2), 20-43. doi:10.1525/cmr.2016.58.2.20

13. Niko Ibrahim and Verliyantina, (2012) The models of CF to support small and micro businesses in Indonesia through a web based platform. 